\title{
Development of dominant follicles and length of ovarian cycles in post-partum dairy cows*
}

\author{
J. D. Savio $\nmid$, M. P. Boland $\ddagger$ and J. F. Roche $\dagger$ \\ $\dagger$ Faculty of Veterinary Medicine, University College Dublin, Ballsbridge, Dublin 4, Ireland; and \\ $\ddagger$ Faculty of Agriculture, University College Dublin, Lyons Estate, Newcastle, Co. Dublin, Ireland
}

\begin{abstract}
Summary. The resumption of ovarian activity after normal calvings was studied in 18 lactating Friesian cows. Since, in 17 cows, first post-partum ovulation occurred without overt oestrous behaviour being detected, the resultant cycles were called 'ovarian cycles'. The mean ( \pm s.d.) length of the ovarian cycles was $21.0 \pm 8.7$ days. The duration of cycles tended to be normal (18-24 days) or long ( $\geq 25$ days) when the ovulatory dominant follicles were identified before Day 10 post partum; they were consistently short (9-13 days) when dominant follicles identified after Day 20 post partum ovulated. When such follicles were detected between Days 10 and 20 post partum, long, normal and short ovarian cycles were detected. The number of waves of follicular growth with associated dominant follicles observed during the ovarian cycles tended to be related to cycle length; short cycles had 1 dominant follicle, normal cycles predominantly 2 , and long cycles mostly 3 dominant follicles. The mean ( \pm s.d.) duration of 13 oestrous cycles studied was $23 \cdot 1 \pm 2 \cdot 1$ days. Of these cycles, 7 had 3 and 6 had 2 dominant follicles. The oestrous cycles with 3 dominant follicles had a mean ( \pm s.d.) duration of $24 \cdot 0 \pm 1 \cdot 2$ days and the respective dominant non-ovulatory follicles reached maximum sizes on Days 8 and 18, respectively; oestrous cycles with 2 dominant follicles were $22 \cdot 2 \pm 2.6$ days in duration, and the dominant non-ovulatory follicle reached maximum size by Day 8 . Ovarian follicular development during the first 45 days of pregnancy was characterized by the growth and regression of successive dominant follicles, each lasting 10-12 days. These results show that the first ovarian cycle was predominantly short when the ovulatory dominant follicle was first detected after Day 20 post partum.
\end{abstract}

Keywords: dairy cow; dominant follicle; post partum; ovarian activity; ultrasound

\section{Introduction}

Although the precise mechanisms that control folliculogenesis in cattle are not understood, it is clear that there is sequential growth and atresia of follicles during the oestrous cycle. Rajakoski (1960) suggested that there are 2 waves of follicular growth in heifers, one between Days 1 and 12 and the second between Day 13 and ovulation. Matton et al. (1981), using India ink to monitor follicular development, reported 3 periods of growth of large follicles during the cycle. Ireland \& Roche (1983), using serial slaughter of heifers between Days 3 and 13 of the cycle, provided evidence of 2 periods of growth and atresia of large follicles before the development of the ovulatory follicle, one between Days 3 and 7 and the second between Days 7 and 13. Based on measurements of ovarian venous blood concentrations of oestradiol in heifers, Ireland \& Roche (1987) suggested that there were 3 periods of growth of oestrogen-active follicles during the cycle. By using

\footnotetext{
* Reprint requests to J. F. Roche.

\$resent address: University of Florida, Dairy Science Department, Gainesville, Florida 32601, USA.
} 
ultrasonography to monitor sequential daily growth of individual follicles in the ovaries of heifers, it was shown that there are 3 periods of growth of different dominant follicles in the majority of the heifers during the oestrous cycle (Savio et al., 1988; Sirois \& Fortune, 1988). Other work, however, suggests that it is usual to have 2 periods during the oestrous cycle when large follicles are present in the ovaries of heifers (Pierson \& Ginther, 1987, 1988; Knopf et al., 1989). It is therefore not clear which factors affect the rate of growth, development and initiation of atresia of follicles.

The time of resumption of follicular development in post-partum dairy cows has been studied (Savio et al., 1990a): medium-sized follicles were present by Day 5 after calving and the detection of a single large dominant follicle was, generally, closely related to the resumption of ovarian cyclicity. Therefore, the aim of this experiment was to determine the pattern of growth and regression of dominant follicles in dairy cows during resumption of cyclicity, by daily ultrasound examinations and concurrent measurement of the concentrations of progesterone and oestradiol in blood. In addition, follicular dynamics during early pregnancy were studied.

\section{Materials and Methods}

Eighteen lactating Friesian cows were checked for oestrus twice daily and their ovaries were scanned daily from 5 days post partum until they were inseminated. The ultrasound machine and the method of scanning the ovaries and the parameters of follicle measurement used were the same as described previously (Savio et al., 1988). Simultaneously with each ultrasound examination, the cows were bled by jugular puncture and the resultant plasma samples were stored at $-20^{\circ} \mathrm{C}$ until they were assayed for progesterone and oestradiol as described by Savio et al. (1990a). The data presented refer to characteristics of growth and regression of dominant follicles after the formation of the first dominant follicle (Savio et al., 1990a). To plot the progesterone concentrations in the same figures, the data were centralized around the day of oestrus, and to draw the profiles the 10-day periods before oestrus were used; afterwards the figures were completed using the number of days necessary to complete the average oestrous cycle, beginning from Day 1. Differences between follicles (size and day of maximum diameter) in cycles with 3 dominant follicles were tested using Tukey's Multiple Comparisons Test. Data from cycles with 2 dominant follicles were analysed using a two-sample $t$ test to compare means (Snedecor \& Cochran, 1980).

The data from the pregnant cows were obtained from 3 cows that conceived to AI during the experiment. Their ovaries were scanned and blood samples were taken daily during the first $\mathbf{4 5}$ days of pregnancy.

\section{Results}

In 17 of $18(94 \%)$ cows that did not develop cysts, the first post-partum ovulation was not accompanied by detected signs of oestrus; it therefore appears more appropriate to call them ovarian cycles, and to use the term oestrous cycles when ovulations were accompanied by detectable signs of oestrus.

\section{First post-partum ovarian cycles}

The mean length ( \pm s.d.) of the first post-partum ovarian cycle was $22 \cdot 2 \pm 8 \cdot 7$ days (range 9-36 days). If the cycles are categorized according to the criteria of Hansel \& McEntee (1977), then 5 $(28 \%)$ ovarian cycles were normal, $5(28 \%)$ were short (9-13 days), and $8(44 \%)$ were long ( $\geq 25$ days). The mean length ( \pm s.d.) and range of variation of the different types of ovarian cycle in the present study were: short $=11.2 \pm 1.8$ days (range 9-13), normal $=20.6 \pm 2 \cdot 2$ days (range 18-24) and long $=30 \cdot 0 \pm 4 \cdot 5$ days (range 25-36). Detection of a dominant follicle before or on Day 9 after calving which subsequently ovulated resulted in ovarian cycles which were either normal or long (Table 1). When the ovulatory dominant follicles were detected between Days 10 and 19, the resultant ovarian cycles were mainly long, although 2 short cycles and 1 normal ovarian cycle were also recorded. However, when the ovulatory dominant follicle was detected after Day 20 post partum, the resultant ovarian cycles were consistently short.

In relation to the number of dominant follicles detected during the first post-partum ovarian cycle, it can be seen from data in Table 2 that only 1 dominant follicle was detected in all 5 cows 
Table 1. Classification of the ovarian cycles according to their lengths (short: 9-13 days, normal: 18-24 days, long: $\geq 25$ days) and the number of days after calving at which the dominant ovulatory follicle was identified in postpartum dairy cows

\begin{tabular}{lcccc}
\hline $\begin{array}{l}\text { Days post partum } \\
\text { when ovulatory } \\
\text { follicle identified }\end{array}$ & $\begin{array}{c}\text { No. of } \\
\text { cows }\end{array}$ & \multicolumn{4}{c}{ Type of ovarian cycle } \\
\hline$\leqslant 9$ & 7 & - & 4 & 3 \\
$10-19$ & 8 & 2 & 1 & 5 \\
$\geq 20$ & 3 & 3 & - & - \\
\hline
\end{tabular}

that had short first ovarian cycles. Consequently, in all short ovarian cycles the first dominant follicle was the ovulatory one (Fig. 1). In the 5 cows that had normal ovarian cycles, 4 had 2 dominant follicles (Fig. 2a) and 1 had 3 dominant follicles (Fig. 2b). Regarding the 8 cows that had long ovarian cycles, 3 had 2 dominant follicles, 4 had 3 and 1 cow had 4 dominant follicles during the cycle (Fig. 3).

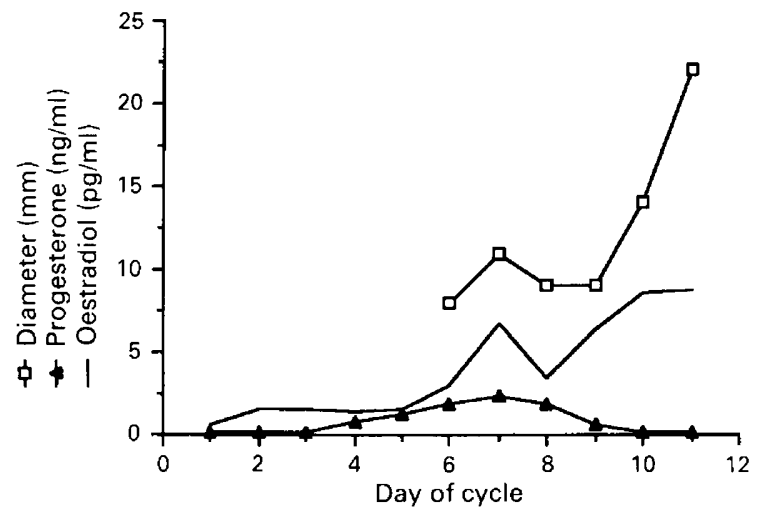

Fig. 1. Pattern of growth of the first dominant follicle, which subsequently ovulated, and associated concentrations of progesterone and oestradiol in plasma of a post-partum cow with a short (9-13 days) ovarian cycle. Day 1 of the short cycle is Day 15 post partum.

\section{Oestrous cycles}

The mean length ( \pm s.d.) of the oestrous cycles studied was $23 \cdot 1 \pm 2 \cdot 1$ days. In 7 cycles $(54 \%)$, 3 dominant follicles were identified (Fig. 4b), and in the remaining 6 oestrous cycles (46\%) 2 dominant follicles were detected (Fig. 4a).

Oestrous cycles with 3 dominant follicles. The mean length ( \pm s.d.) of the cycles with 3 dominant follicles was $24 \cdot 0 \pm 1 \cdot 2$ days (range 23-26 days). The patterns of growth and regression of dominant follicles during such oestrous cycles are shown in Fig. 4. The first dominant follicle was initially identified about Day 4 (range Days 1-6), reached its maximum size (day of maximum diameter) by Day 8 (range Days 6-11) and was observed until Day 19 (range Days 15-24). The period between the day of initial detection and the day of maximum size was characterized by a consistent increase in size between successive examinations. From the day of maximum diameter to, approximately, Day 14, the mean diameter did not vary; nevertheless, when patterns of development in individual cows were observed, it could be seen that some secondary growth may be 


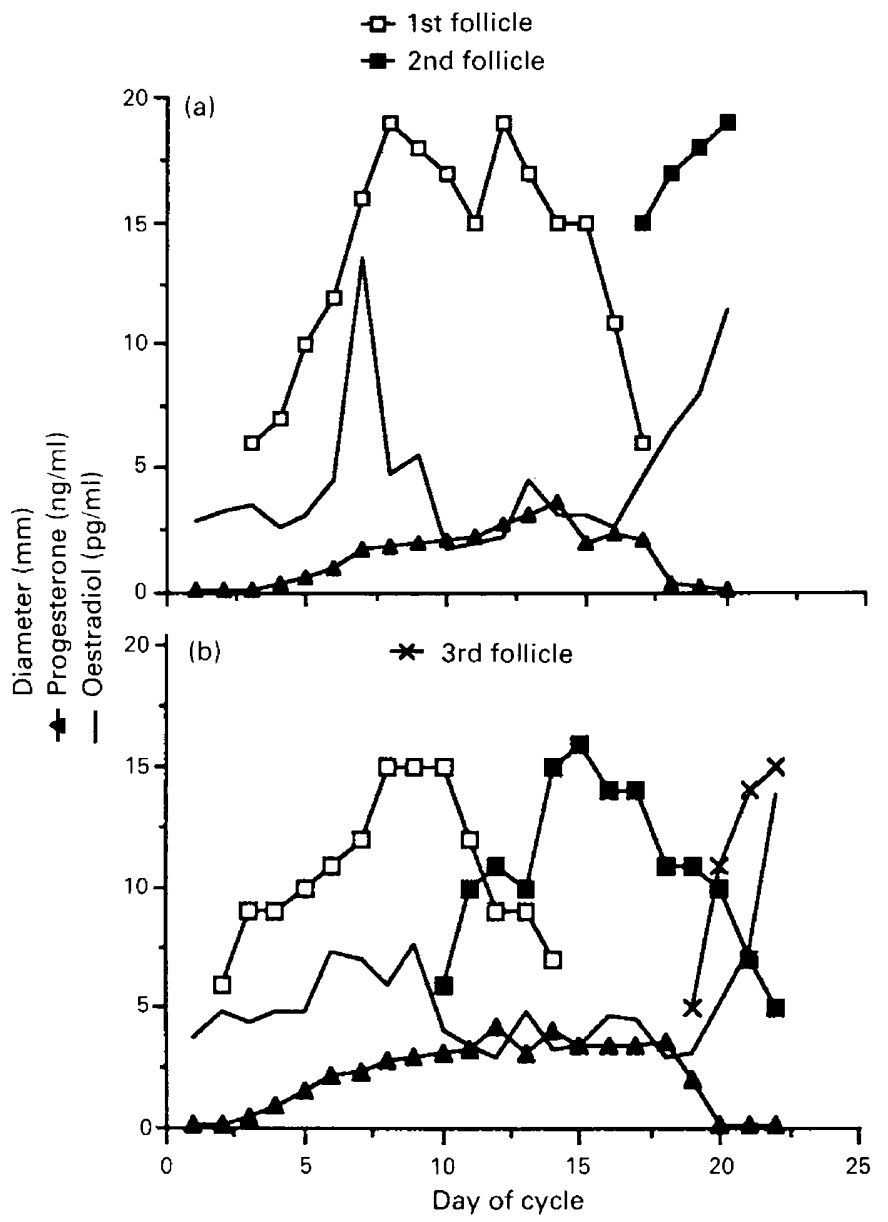

Fig. 2. Pattern of growth of the dominant follicles where (a) the second or (b) the third follicle ovulated, and associated concentrations of progesterone and oestradiol of cows with normal (18-24 days) ovarian cycles. Day 1 of the normal cycle in (a) is Day 10 and in (b) is Day 41 post partum.

observed around Days 9, 10 or 11 (Fig. 3a). From Day 15 onwards the diameter consistently decreased until it was no longer detectable at Day 19 on average.

The second dominant follicle was identified, on average, by Day 14 (range 11-16), reached maximum diameter by Day 18 (range Days 15-21) and then decreased in size steadily during successive observations until Day 22 (range Days 20-25). The period of regression of the second dominant follicle was initiated either immediately after the maximum size was reached (in 4 cycles) or after a short period of stability of 2 or 3 days (in 3 cycles). The third dominant (ovulatory) follicle was observed from Day 19 (range Days 18-21) and after a period of sustained growth reached maximum diameter, generally on the day of oestrus.

In relation to other characteristics related to the growth and regression of such dominant follicles, data in Table 3 show that the day at which each class of dominant follicle reached maximum size was significantly different among follicles $(P<0.01)$. The first dominant follicle had a significantly longer duration of detection and duration of atresia $(P<0.05)$ as well as slower rate of atresia $(P<0.05)$ compared with the second as described by Savio et al. (1988). Finally, no significant difference $(P>0 \cdot 10)$ was found in the parameters related to growth (growth rate and duration of growth) and maximum diameter. 


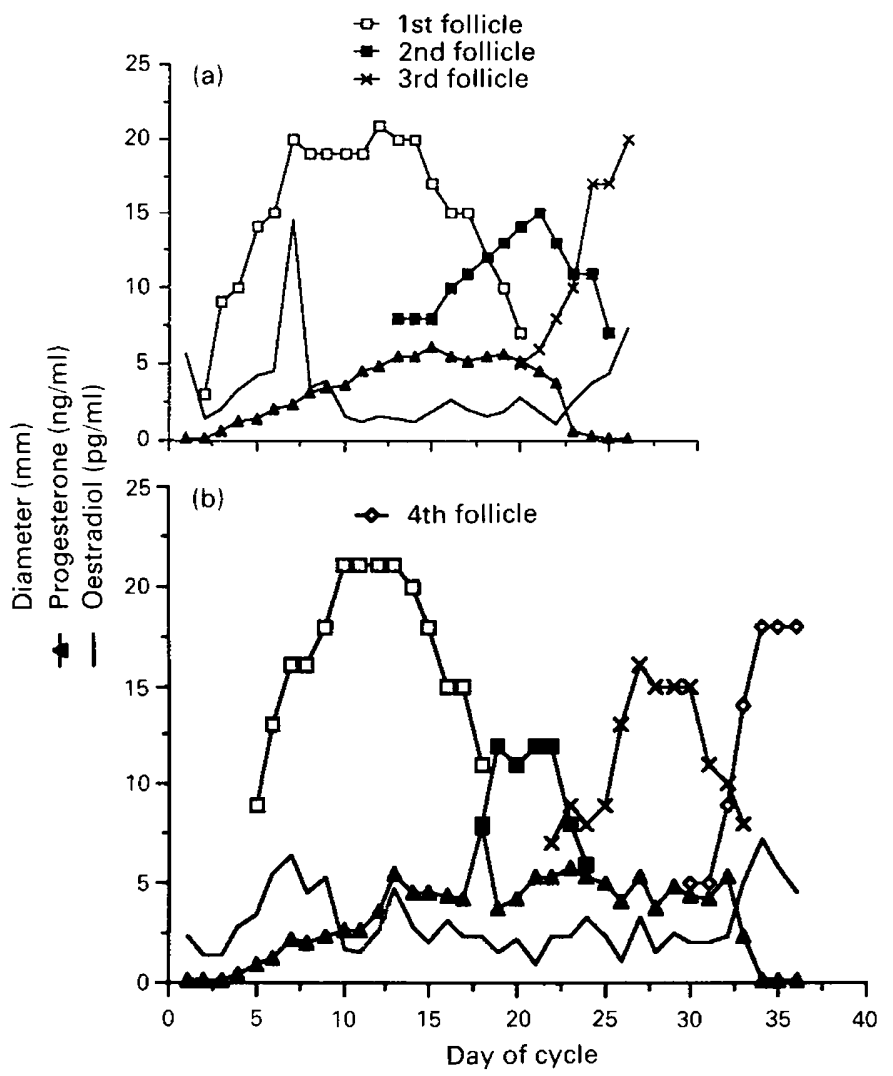

Fig. 3. Pattern of growth of dominant follicles when (a) the 3rd and (b) the 4th dominant follicle ovulated associated with progesterone and oestradiol concentrations in post-partum cows with long (25-36 days) ovarian cycles. Day 1 of the cycle for cow in (a) was Day 28 and in (b) was Day 11 post partum.

Table 2. Number of dominant follicles detected according to ovarian cycle length (short: 9-13 days, normal: $18-24$ days, long: $\geq 25$ days) in postpartum dairy cows

\begin{tabular}{|c|c|c|c|c|c|}
\hline \multirow{2}{*}{$\begin{array}{l}\text { Length of } \\
\text { ovarian cycles }\end{array}$} & \multirow{2}{*}{$\begin{array}{l}\text { No. of } \\
\text { cycles }\end{array}$} & \multicolumn{4}{|c|}{$\begin{array}{c}\text { No. of } \\
\text { dominant follicles }\end{array}$} \\
\hline & & 1 & 2 & 3 & 4 \\
\hline Short & 5 & 5 & - & - & - \\
\hline Normal & 5 & - & 4 & 1 & - \\
\hline Long & 8 & - & 3 & 4 & 1 \\
\hline
\end{tabular}

Oestrous cycles with 2 dominant follicles. The mean length ( \pm s.d.) of cycles with 2 dominant follicles was $22 \cdot 2 \pm 2.6$ days, which was not different $(P>0 \cdot 10)$ from cycles with 3 dominant follicles. The patterns of growth and regression of dominant follicles during such oestrous cycles are shown in Fig. 4(a). The first dominant follicle was identified by Day 3 (range Days 2-5), reached maximum size by Day 8 (range Days 6-12) and, after a period of stability in size (which showed 


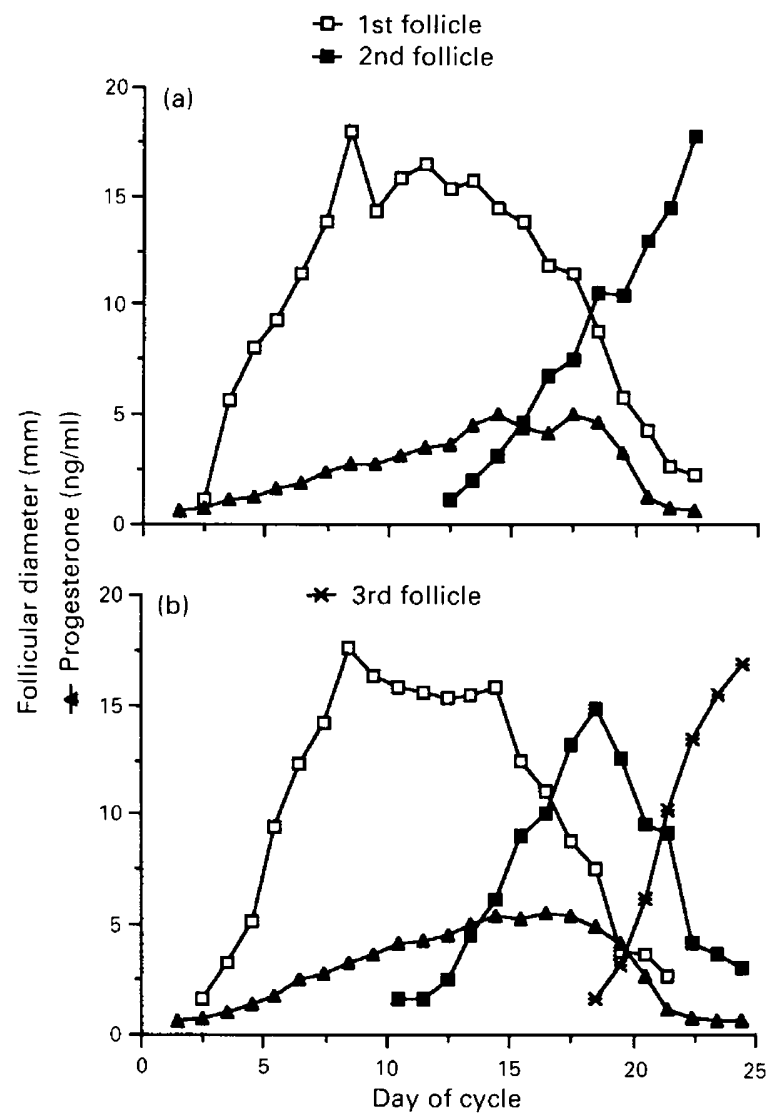

Fig. 4. Growth pattern of dominant follicles of post-partum dairy cows with (a) 2 dominant follicles $(\mathrm{N}=6)$, and (b) 3 dominant follicles $(\mathrm{N}=7)$ during normal oestrous cycles.

Table 3. Mean ( \pm s.d.) follicular parameters obtained during the oestrous cycle of post-partum dairy cows, after daily examinations of the ovaries by ultrasound

\begin{tabular}{|c|c|c|c|c|c|c|c|}
\hline & $\begin{array}{l}\text { Growth } \\
\text { rate } \\
\text { (mm/day) }\end{array}$ & $\begin{array}{l}\text { Duration } \\
\text { of growth } \\
\text { (days) }\end{array}$ & $\begin{array}{l}\text { Duration of } \\
\text { detection } \\
\text { (days) }\end{array}$ & $\begin{array}{l}\text { Maximum } \\
\text { diam. } \\
(\mathrm{mm})\end{array}$ & $\begin{array}{c}\text { Day of } \\
\text { maximum } \\
\text { diam. }\end{array}$ & $\begin{array}{l}\text { Rate of } \\
\text { atresia } \\
\text { (mm/day) }\end{array}$ & $\begin{array}{l}\text { Duration } \\
\text { of atresia } \\
\text { (days) }\end{array}$ \\
\hline \multicolumn{8}{|c|}{ Cycles with 3 dominant follicles $(n=7)$} \\
\hline First & $3.8 \pm 1.9$ & $5 \cdot 1 \pm 1.9$ & $17 \cdot 1 \pm 3 \cdot 5$ & $17 \cdot 1 \pm 2 \cdot 2$ & $7 \cdot 9 \pm 1 \cdot 7$ & $1 \cdot 5 \pm 0 \cdot 3$ & $12 \cdot 0 \pm 3 \cdot 3$ \\
\hline Second & $3.5 \pm 1.9$ & $5 \cdot 1 \pm 2 \cdot 4$ & $10 \cdot 1 \pm 3 \cdot 0$ & $14 \cdot 4 \pm 1 \cdot 3$ & $18 \cdot 0 \pm 2 \cdot 3$ & $3.5 \pm 1.9$ & $5 \cdot 0 \pm 2 \cdot 2$ \\
\hline Third & $3 \cdot 4 \pm 1 \cdot 1$ & $5 \cdot 3 \pm 1 \cdot 5$ & & $16 \cdot 3 \pm 2 \cdot 2$ & $23 \cdot 7 \pm 1 \cdot 4$ & & \\
\hline Significance & N.S. & N.S. & $*$ & N.S. & ** & $*$ & $*$ \\
\hline \multicolumn{8}{|c|}{ Cycles with 2 dominant follicles $(n=6)$} \\
\hline First & $3 \cdot 3 \pm 1 \cdot 0$ & $5 \cdot 7 \pm 2 \cdot 0$ & $18 \cdot 0 \pm 2 \cdot 9$ & $17 \cdot 5 \pm 3 \cdot 6$ & $7 \cdot 8 \pm 2 \cdot 5$ & $1.5 \pm 0.6$ & $12 \cdot 3 \pm 3 \cdot 3$ \\
\hline Second & $3 \cdot 0 \pm 1 \cdot 4$ & $7 \cdot 0 \pm 2 \cdot 8$ & & $17 \cdot 2 \pm 1 \cdot 2$ & $22 \cdot 2 \pm 2 \cdot 6$ & & \\
\hline Significance & N.S. & N.S. & & N.S. & $* *$ & & \\
\hline
\end{tabular}

N.S. not significant; ${ }^{*}$ means within column significantly different, $P<0.05 ;{ }^{* *}$ means within column significantly different, $P<0.01$. 
periods of secondary growth similar to those reported for the same period in the cycles with 3 dominant follicles) between Days 8 and 15, began to decrease in size and was rarely detectable after Day 19 (range Days 16-25). The second dominant (ovulatory) follicle was identified by Day 16 (range Days 10-25), and after a period of growth, generally not continuous, reached maximum size in most cycles on the day of oestrus (Fig. 4a). From data presented in Table 3, it can be seen that no significant differences were detected in any of the parameters examined with the exception of day of maximum diameter, which was significantly different between follicles $(P<0.01)$.

\section{Development of dominant follicles during early pregnancy}

In the 3 pregnant cows examined, the first dominant follicle after AI and the period of growth of the second dominant follicle resembled the patterns reported during comparable stages of the oestrous cycle described above (Fig. 5). However, the rate of regression of the second dominant follicle appeared slower than that observed during oestrous cycles with 3 dominant follicles. After that, periods of growth and regression of dominant follicles were observed throughout early pregnancy (Fig. 5). The different dominant follicles detected during early pregnancy showed variable periods of dominance and, consequently, this resulted in different numbers of dominant follicles being detected during fixed periods of time. In fact, in 2 cows, 3 dominant follicles were observed during the first 30 days of pregnancy and another 2 during the following 15 days, while in the remaining cow, 2 dominant follicles were observed during the first 30 days and another 2 during the following 15 days of pregnancy. Despite the stated variability between animals, the results suggest that the majority of the successive periods of dominance during early pregnancy in the cows had a duration of about 10-12 days each. The patterns of growth and regression of dominant follicles in an individual cow during the first 45 days of pregnancy are shown in Fig. 5.

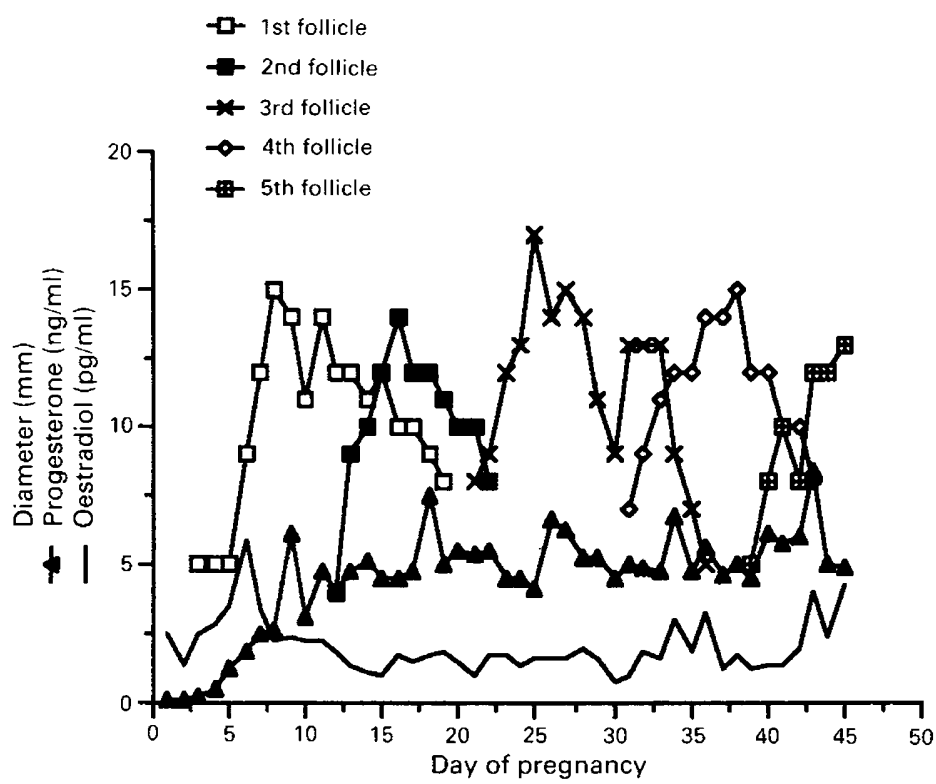

Fig. 5. The growth pattern of successive dominant follicles associated with concentrations of progesterone and oestradiol in plasma of post-partum cows during the first 45 days of pregnancy. 


\section{Concentrations of progesterone and oestradiol}

During ovarian and oestrous cycles, blood concentrations of progesterone began to rise about Day 3 of the cycle and increased to concentrations as high as $8 \mathrm{ng} / \mathrm{ml}$ during the luteal phase before returning to basal levels $(<0.5 \mathrm{ng} / \mathrm{ml})$, usually $2-4$ days before ovulation. The mean progesterone concentrations for different ovarian cycle lengths are shown in Fig. 6. It is evident that the mean daily concentrations are similar during equivalent periods, and that the only difference in progesterone concentrations in cycles of different length appear to be related to initiation of luteolysis at different times after the initiation of the cycles. The patterns of progesterone concentrations in cycles characterized by 2 or 3 dominant follicles (Fig. 4) showed an initial rising period between Days 3 and 10, which was followed by a plateau of approximately 7 days duration. Finally, from Day 17, a 3- or 4-day period of decreasing concentrations occurred until basal values were reached on Days 20-21 of the cycle. Although the average pattern of progesterone secretion might suggest a gradual period of increasing, maintenance and decreasing rates of hormonal secretion, the profiles of progesterone concentrations of individual oestrous cycles of cows indicate that there is individual variation between days. In fact, except during the period of luteolysis when the decline is steady, it is possible to observe 2-3 days of increased secretion during the luteal phases of the oestrous cycles in the individual animals (Figs 2a \& 3). Such periods of increased concentrations of progesterone were generally observed coincident with growth phases of different dominant follicles.

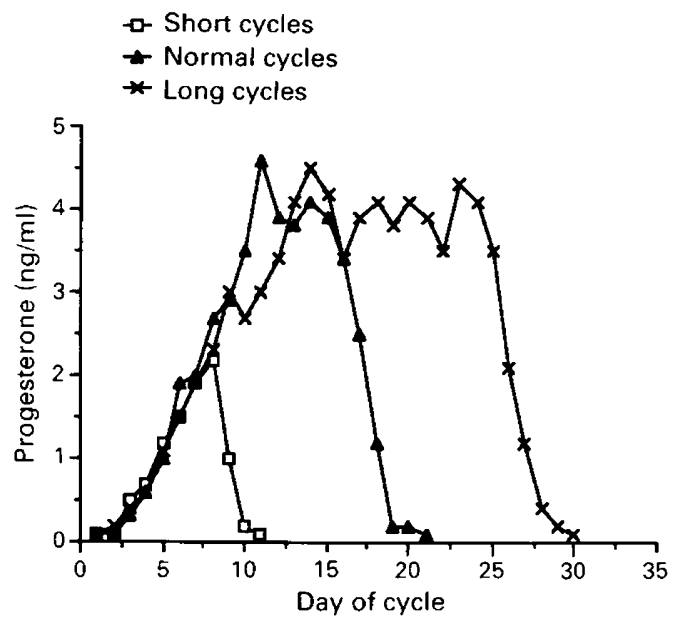

Fig. 6. Mean daily concentrations of progesterone in post-partum cows having short, normal or long ovarian cycles.

Increases of variable magnitude in circulating oestradiol were consistently detected coincident with the development of the different dominant follicles (Figs 1-3); nevertheless, the peaks were generally higher when they corresponded to dominant ovulatory follicles than those observed for dominant non-ovulatory follicles.

\section{Discussion}

The high percentage of cows in which external signs of oestrus were not observed with first postpartum ovulation agrees with the data of Zemjanis (1980) who suggested that 'silent' ovulations are physiologically normal in the post-partum period in cattle. 
The first post-partum ovarian cycles were also characterized by variability in length. Although the data in this study are not sufficient to support definitive conclusions, they show interesting trends when lengths of the ovarian cycles are classified according to the day of detection of the first post-partum dominant ovulatory follicle. When the ovulatory follicles were detected during the early post-partum period ( $<10$ days), the resultant ovarian cycles were normal or long; when the dominant follicles were detected between Days 10 and 20, normal, long and short ovarian cycles were observed; and finally, the ovarian cycles resulting from dominant follicles detected after Day 20 post partum were all short (Table 1). Although there is no definitive explanation for the abnormal cycle lengths, the data show that long cycles were more common during the early postpartum period. The length of the oestrous cycle depends on the lifespan of the corpus luteum, and the principal luteolytic factor in cattle is prostaglandin F-2 $\alpha$ of endometrial origin (Thatcher et al., 1984). This suggests post-partum endometrial deficiencies as a possible cause of extended luteal function. Considering that restoration of the caruncular endometrium [which in sheep produces prostaglandin $\mathrm{F}$ in vitro at a higher rate than the intercaruncular endometrium (Findlay et al., 1981)] occurs in cattle about 25 days after calving (Gier \& Marion, 1968), it seems reasonable to postulate that a deficiency in the production of prostaglandin F-2 $\alpha$ may explain the occurrence of some long ovarian cycles in the early post-partum period. However, the implication of other components or factors that may affect the function of the luteolytic system cannot be ignored.

When ovulation is induced by GnRH injection after an anoestrous period in cattle (Troxel \& Kesler, 1984) or sheep (McLeod et al., 1982), short cycles frequently occur. Normal duration of ovarian cycles can be achieved by injection of progesterone before the GnRH treatment in sheep (McLeod et al., 1982) and cattle (Smith et al., 1987). Progesterone priming is necessary for normal oestrogen production and the development of $\mathrm{LH}$ receptors in the preovulatory follicles of the ewe (Hunter et al., 1986) and cow (Inskeep et al., 1988), and in the majority of cows in the present study, when the first dominant follicle ovulated on or before Day 15 post partum, the subsequent ovarian cycle was of normal or long duration. However, when the first ovulations occurred after Day 20 , this consistently resulted in short ovarian cycles. If progesterone priming of the follicles in the early post-partum period by the corpus luteum of pregnancy is assumed, it could explain some of the variation in the length of the cycles and suggest that the duration of the effectiveness of the postulated progesterone priming from late pregnancy may be effective for the next 15 days after calving. On the other hand, although the concentrations of progesterone in cows with different ovarian cycle lengths were similar until Day 8 (Fig. 6), the corpora lutea from the first post-partum ovulations were reported to be smaller than those of subsequent ovulations (Duby et al., 1985), and had reduced ability to support pregnancy (Ramirez-Godinez et al., 1981). The ovary might therefore be able, by as yet unknown mechanisms, to identify a defective corpus luteum and eliminate it through an early activation of the luteolytic system.

The data from this study indicate that $54 \%$ of the oestrous cycles monitored in lactating dairy cows early post partum had 3 dominant follicles, and 2 dominant follicles were observed in the remaining cycles. These results differ from the pattern of growth and regression of dominant follicles reported for beef heifers (Savio et al., 1988; Sirois \& Fortune, 1988). In addition, the average day of maximum diameter of the successive dominant follicles observed in the present study showed a delay of about 2 days in comparison to the same parameter previously observed in heifers (Savio et al., 1988). This might explain why the oestrous cycles of cows were $2-3$ days longer than those in heifers with the same number of dominant follicles. Similarly, this slower rate of growth of follicles and greater number of cycles with 2 dominant follicles in post-partum cows suggest that the dynamics of follicular development may be different in post-partum dairy cows and heifers. This apparently slower growth rate of follicles might also help explain the wider spread in the onset of oestrus in dairy cows than in heifers following luteolysis induced by prostaglandin F-2 $\alpha$ injection at midcycle (Roche \& Ireland, 1984). In heifers, it has been suggested (Savio et al., 1988) that the duration of the period of dominance of the first dominant follicle may be the key to determining the 
number of subsequent dominant follicles that are present during each oestrous cycle. In effect, although the difference in the length of the oestrous cycles with 2 or 3 dominant follicles in the present study was not significant, the pattern of development and regression of the first dominant follicle in the cycles with 3 dominant follicles (Fig. 4b) suggests that the beginning of the regression period may be about Day 14, while in cycles with 2 dominant follicles (Fig. 4a) the mean day of regression was Day 16. The mean time of regression of the first dominant follicle in both lengths of oestrous cycles coincided with the mean day of identification of the second dominant follicle. It is not clear from these data whether the initiation of regression of the dominant follicle allows the development of a new dominant follicle or whether the appearance of a new dominant follicle induces regression of the current dominant follicle.

In relation to variations in size of follicles, the analysis of patterns of follicular development in individual cycles suggests that the increases in size during periods of development (e.g. between the day of identification and day of maximum size) reflect increasing degrees of follicular maturity, as was demonstrated with ovulation of the majority of the first dominant follicles after injection of prostaglandin F-2 $\alpha$ on Day 7 of the oestrous cycle (Savio et al., 1990b). Nevertheless, this observation might not be accurate if it is applied to the secondary periods of growth, especially observed during the period of stability of the first dominant follicle in heifers (Savio et al., 1988) and again consistently observed in the present study in cows. In addition, it is not clear why these periods of growth were generally observed during the days before the identification of a new dominant follicle. Considering that increases in FSH were reported in cattle during the luteal phase (Schams $e t$ al., 1977; Ireland \& Roche, 1983), and that the granulosa layer of atretic follicles of sheep regenerated in culture, in response to the addition of FSH (Hay et al., 1979), it is possible that the secondary periods of growth frequently detected in the first dominant follicle in cattle might be a secondary effect of increased gonadotrophic stimulus to initiate the development of a new dominant follicle. Consequently, the ultrasonographic data from heifers and cows could suggest that a prolongation of function or some kind of a temporary rescue of atretic follicles, as previously reported for mice (Peters et al., 1975), might occur around midcycle in cattle, although Hirshfield (1989) suggested that atresia is difficult to reverse.

The delayed identification of the second dominant follicle in cycles with 2 dominant follicles means that, in such cycles, the second dominant follicle had a greater chance to respond to the increased gonadotrophic stimulation resulting from the removal, after luteolysis, of the negative feedback effect of progesterone on gonadotrophin secretion (Ireland \& Roche, 1982). This observation might explain the apparently different patterns of growth of the ovulatory follicles, frequently observed in individual cycles. In fact, the ovulatory follicles in cycles with 3 dominant follicles generally showed a linear growth pattern, while the ovulatory follicles of cycles with 2 dominant follicles frequently exhibited a slower, more gradual, and sometimes irregular, growth pattern (Fig. 4a).

This suggestion that the failure of the second dominant follicle to respond correctly to the gonadotrophic stimulation at the time of luteolysis is the cause for the development of a third (generally ovulatory) dominant follicle in some cycles in cattle is further substantiated by the patterns of development of dominant follicles during early pregnancy in cows (Fig. 5). The patterns of growth and regression of the various dominant follicles, detected during early pregnancy, were similar, and no accelerated regression of the second dominant follicles, as in the oestrous cycles with 3 dominant follicles, was detected. In addition, it suggests that the role of follicles in the mechanism of luteolysis in cattle (Villa-Godoy et al., 1985) is secondary, and the follicles are therefore necessary components of the luteolytic system which may be activated by other unknown components.

We thank Mr M. Hegarty for help during ultrasound examinations; the staff at Lyons Estate for care of the animals; Mrs M. R. Mattiacci for help in analysing the data; Ms N. Hynes and Mr G. Claffey for the hormone assays; and Miss M. Phelan for secretarial assistance. 


\section{References}

Duby, R.T., Browning, T., Carey, D. \& Black, D.L. (1985) Progesterone synthesis and histology of postpartum bovine corpora lutea. Theriogenology 23, $619-630$

Findlay, J.K., Ackland, N., Burton, R.D., Davis, A.J., Maule Walker, F.M., Walters, D.E. \& Heap, R.B. (1981) Protein, prostaglandin and steroid synthesis in caruncular and intercaruncular endometrium of sheep before implantation. J. Reprod. Fert. 62 , 361-377.

Gier, H.T. \& Marion, G.B. (1968) Uterus of the cow after parturition: Involutional changes. Am. J. vet. Res. 29, 83-96.

Hansel, W. \& McEntee, K. (1977) Female reproductive processes. In Duke's Physiology of Domestic Animals, 9th edn, pp. 772-800. Ed. M. J. Swenson. Cornell University Press, Ithaca.

Hay, M.F., Moor, R.M., Cran, D.G. \& Dott, H.M. (1979) Regeneration of atretic sheep ovarian follicles in vitro. J. Reprod. Fert. 55, 195-207.

Hirshfield, A.N. (1989) Rescue of atretic follicles in vitro and in vivo. Biol. Reprod. 40, 181-190.

Hunter, M.G., Southee, J.A., McLeod, B.J. \& Haresign, W. (1986) Progesterone pretreatment has a direct effect on GnRH-induced preovulatory follicles to determine their ability to develop into normal corpora lutea in anoestrous ewes. J. Reprod. Fert. 76, 349-363.

Inskeep, E.K., Braden, T.D., Lewis, P.E., Garcia-Winder, M. \& Niswender, G.D. (1988) Receptors for luteinizing hormone and follicle-stimulating hormone in largest follicles of postpartum beef cows. Biol. Reprod. 38, 587-591.

Ireland, J.J. \& Roche, J.F. (1982) Effect of progesterone on basal LH and episodic LH and FSH secretion in heifers. J. Reprod. Fert. 64, 295-302.

Ireland, J.J. \& Roche, J.F. (1983) Development of non-ovulatory antral follicles in heifers: changes in steroids in follicular fluid and receptors for gonadotrophins. Endocrinology 112, 150-156.

Ireland, J.J. \& Roche, J.F. (1987) Hypotheses regarding development of dominant follicles during a bovine estrous cycle. In Follicular Growth and Ovulation Rate in Farm Animals, pp. 1-18. Eds J. F. Roche \& D. O'Callaghan. Martinus Nijhoff, The Hague.

Knopf, L., Kastelic, J.P., Schallenberger, E. \& Ginther, O.J. (1989) Ovarian follicular dynamics in heifers: test of twin wave hypothesis by ultrasonically monitoring individual follicles. Dom. Anim. Edocr. 6, $111-119$.

McLeod, B.J., Haresign, W. \& Lamming, G.E. (1982) Response of seasonally anoestrous ewes to small dose multiple injections of GnRH with and without progesterone pretreatment. J. Reprod. Fert. 65, 223-230.

Matton, P., Adelakoun, V., Couture, Y. \& Dufour, J.J. (1981) Growth and replacement of the bovine ovarian follicles during the estrous cycle. J. Anim. Sci. 52, 813-820.

Peters, H., Byskov, A.G., Himelstein-Braw, R. \& Faber, M. (1975) Follicular growth: the basic event in the mouse and human ovary. $J$. Reprod. Fert. 45, $559-566$.
Pierson, R.A. \& Ginther, O.J. (1987) Follicular populations during the estrous cycles in heifers. 1. Influence of day. Anim. Reprod. Sci. 14, 165-176.

Pierson, R.A. \& Ginther, O.J. (1988) Ultrasonic imaging of the ovaries and uterus in cattle. Theriogenology 29, 21-37.

Rajakoski, R. (1960) The ovarian follicular system in sexually mature heifers with special reference to seasonal, cyclical and left-right variations. Acta endocr., Copenh., Suppl. 52, 1-68.

Ramirez-Godinez, J.A., Kiracofe, G.H., McKee, R.M., Schalles, R.R. \& Kittok, R.J. (1981) Reducing the incidence of short estrous cycles in beef cows with norgestomet. Theriogenology 15, 613-623.

Roche, J.F. \& Ireland, J.J. (1984) Manipulation of ovulation in cattle. Proc. 10th Int. Congr. Anim. Reprod. \& A.I., Urbana-Champaign, Vol. IV, 9-17.

Savio, J.D., Keenan, L., Boland, M.P. \& Roche, J.F. (1988) Pattern of growth of dominant follicles during the oestrous cycle of heifers. J. Reprod. Fert. 83, $663-671$.

Savio, J.D., Boland, M.P., Hynes, N. \& Roche, J.F. (1990a) Resumption of follicular activity in the early post-partum period of dairy cows. J. Reprod. Fert. 88, 569-579.

Savio, J.D., Boland, M.P., Hynes, N., Mattiacci, M.R. \& Roche, J.F. (1990b) Will the first dominant follicle of the cycle of heifers ovulate following luteolysis on day 7? Theriogenology (in press).

Schams, D., Schallenberger, E., Hoffman, B. \& Karg, H. (1977) The oestrous cycle of the cow: Hormonal parameters and time relationships concerning oestrus, ovulation, and electrical resistance of the vaginal mucus. Acta endocr., Copenh. 86, 180-192.

Sirois, J. \& Fortune, J.E. (1988) Ovarian follicular dynamics during the estrous cycle in heifers monitored by real-time ultrasonography. Biol. Reprod. 39, 308-317.

Smith, V.G., Chenault, J.R., McAllister, J.F. \& Lauderdale, J.W. (1987) Response of postpartum beef cows to exogenous progestogens and gonadotropin releasing hormone. J. Anim. Sci. 64, 540-551.

Snedecor, G.W. \& Cochran, W.G. (1980) Statistical Methods, 7 th edn. Iowa State University Press, Ames.

Thatcher, W.W., Bartol, F.F., Knickerbocker, J.J., Curl, J.S., Wolfenson, D., Bazer, F.W. \& Roberts, R.M. (1984) Maternal recognition of pregnancy in cattle. $J$. Dairy Sci. 67, 2797-2811.

Troxel, T.R. \& Kesler, D.J. (1984) The effect of progestin and GnRH treatments on ovarian function and reproductive hormone secretions of anestrous postpartum suckled beef cows. Theriogenology 21, 699-711.

Villa-Godoy, A., Ireland, J.J., Wortman, J.A., Ames, N.K., Hughes, T.L. \& Fogwell, R.L. (1985) Effect of ovarian follicles on luteal regression in heifers. $J$. Anim. Sci. 60, 519-527.

Zemjanis, R. (1980) Anestrus in cattle. In Current Therapy in Theriogenology, pp. 193-198. Ed. D. A. Morrow. W. B. Saunders, Philadelphia.

Received 24 August 1989 